\title{
Identification of stomach contents from a Shepherd's beaked whale Tasmacetus shepherdi stranded on Tristan da Cunha, South Atlantic
}

\author{
P.B. BEST ${ }^{1}$, M.J. SMALE ${ }^{2}$, J. GLASS ${ }^{3}$, K. HERIAN ${ }^{4}$ AND S. VON DER HEYDEN ${ }^{5}$ \\ ${ }^{1}$ Mammal Research Institute, University of Pretoria, c/o Iziko South African Museum, PO Box 61, Cape Town, 8ooo, South Africa, \\ ${ }^{2}$ Port Elizabeth Museum at Bayworld, Bayworld Centre for Research and Education, PO Box 13147, Humewood, 6013 South Africa, \\ and Department of Zoology, Nelson Mandela Metropolitan University, PO Box 7700o, Port Elizabeth, 6031, South Africa, ${ }^{3}$ Director \\ of Fisheries, Fisheries Department, Tristan da Cunha Government, South Atlantic Ocean, ${ }^{4}$ Royal Society for the Protection of Birds \\ Project Officer, Conservation Department, Tristan da Cunha, South Atlantic Ocean, ${ }^{5}$ Evolutionary Genomics Group, Department of \\ Botany and Zoology, Stellenbosch University, Private Bag X1, Matieland, 7602 South Africa
}

\begin{abstract}
Shepherd's beaked whale Tasmacetus shepherdi is one of the most poorly known cetaceans, whose diet has created some speculation given that its dentition differs greatly from that of most other beaked whales that are primarily teuthophagous. The few stomachs examined previously have given seemingly conflicting dietary information. In this paper the stomach contents of a freshly stranded adult female on Tristan da Cunha have been examined through identification of trace elements and genetic analysis of soft parts. At least 13 cephalopod and 8 fish species were identified from beaks and otoliths respectively, but only undigested fish remains were present in the stomach and identified genetically as Beryx splendens. Reconstituted masses totaled $8809 \mathrm{~g}$ for cephalopods and $17,554 \mathrm{~g}$ for fish, with four species (Histioteuthis atlantica, Taningia danae, Ommastrephes bartrami and Pholidoteuthis ' $A$ ') comprising $78.6 \%$ of the cephalopods and one species (B. splendens) comprising $87.4 \%$ of the fish eaten. It is concluded that Tasmacetus may alternately exploit fish and cephalopods, depending on the time of day and access to seamount or continental slope areas.
\end{abstract}

Keywords: Shepherd's beaked whale, food, South Atlantic, cephalopods, fish, Beryx splendens, feeding behaviour

Submitted 11 September 2012; accepted 30 September 2012; first published online 21 November 2012

\section{INTRDDUCTION}

Shepherd's beaked whale Tasmacetus shepherdi Oliver 1937 is one of the least known cetaceans. Until 2005 it was known only from 42 strandings ( 24 in New Zealand) and five sightings, and it seems to have a circumpolar distribution in deep, cold temperate waters of the Southern Ocean (Pitman et al., 2006).

Tasmacetus shepherdi is unique amongst members of the family Ziphiidae in possessing numerous teeth in both upper and lower jaws that erupt in adults and juveniles of both sexes, apart from an apical pair in the lower jaw that probably only erupts in adult males (Mead \& Payne, 1975). This has led to much speculation about their diet: given that most other members of the family in which dentition is restricted to one or two pairs in the lower jaw (that erupt in adult males only) are teuthophagous, it has been assumed that the species' diet may contain a larger proportion of fish (Mead, 1989).

However, available information on the diet of Tasmacetus is confined to the examination of the stomachs of four

Corresponding author:

P.B. Best

Email: pbest@iziko.org.za stranded specimens (only two of which are informative) and is somewhat equivocal on this point. In a male from Argentina Mead \& Payne (1975) recorded the presence of the well-digested remains of several fish (mostly an unidentified brotulid, but also Merluccius hubbsi Marini, 1933 and an unidentified serranid), a small crab Peltarion spinulosum (White, 1843) and one small unidentified squid beak: the latter two were believed to be prey of the fish. In an unsexed whale from Tristan da Cunha, however, only cephalopod remains were found, consisting of single beaks or buccal masses of Todarodes filippovae Adam, 1975, Teuthowenia pellucida (Chun, 1910), Ancistrocheirus lesueri (Orbigny, 1842), Histioteuthis (?corpuscula) and one unidentified species: all eye lenses present were also from cephalopods (Pitman et al., 2006). The other two records consist of a calf containing plastic debris (Mead, 2009), and an adult male from Argentina in which five longline hooks were discovered in the stomach and intestines (Goodall et al., 2008).

In this paper we present new information on feeding habits based on the examination of the stomach contents of an adult female stranded at Tristan da Cunha in 2012. As there are no licensed trawling or long-line fishing operations in Tristan da Cunha's exclusive economic zone, it is unlikely that these contents could reflect depredation from fisheries. 


\section{MATERIALS AND METHODS}

On 13 January 2012 two Shepherd's beaked whales stranded alive close to the Settlement on the north-west corner of Tristan da Cunha, South Atlantic $\left(37^{\circ} 3.84^{\prime} \mathrm{S} 12^{\circ} 17.87^{\prime} \mathrm{W}\right)$, the seventh and eighth respectively to have been recorded as stranding there (Pitman et al., 2006). Both died shortly after stranding: the body of the larger, a female, lay somewhat offshore on a reef and consequently suffered considerable damage from the sea and sharks. When finally measured much of the beak had been destroyed so that only an approximate length $(6.75 \mathrm{~m})$ was possible. The second animal was a sub-adult male $5.05 \mathrm{~m}$ long (Figure 1 ). Both sexes were determined externally and confirmed via photographic images: no reproductive material was collected but the presence of milk in the female was tested for by squeezing the nipple externally and cutting open some of the mammary ducts for up to $30-40 \mathrm{~cm}$ : none was found.

On 16 and 17 January the carcasses were dissected and both stomachs examined. That of the male proved to be empty, but the contents of the female's stomach were removed and frozen (as were the stomachs themselves) and later shipped to Cape Town.

In the laboratory the pre-separated contents were defrosted and sorted by hand into skeletal fragments and adhering tissue, eye lenses and trace remains such as cephalopod beaks and fish otoliths, while some soft prey tissue was subsampled and fixed in $70 \%$ alcohol for genetic analysis. All component items were weighed before preservation. In a separate operation the stomach linings were defrosted and washed under a tap into a flat container: during this operation the mucosa was also searched with forceps and trace remains that were not flushed out were collected. Any fish skulls were later examined for the presence of otoliths. All otoliths were washed briefly in alcohol, rinsed in water and air-dried. All other material was preserved permanently in $70 \%$ alcohol.

Beaks were identified by comparison with material in the Port Elizabeth Museum (PEM) cephalopod beak collection and using literature (Clarke, 1986; Xavier \& Cherel, 2009). Effort was focused on lower beaks for identification and measurement (Clarke, 1986). Lower beaks were counted and measured and morphometric relationships in the literature or developed at the PEM were used to estimate the dorsal mantle length (DML) and masses of each one using the rostral length (RL) for squid (Clarke, 1986).

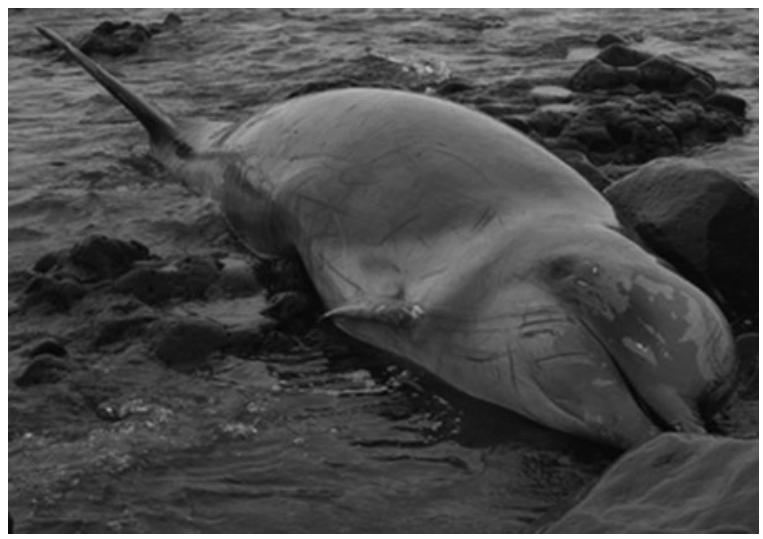

Fig. 1. A juvenile male Tasmacetus shepherdi stranded on Tristan da Cunha, 13 January 2012 (photograph: Katrine Herian).
Otoliths were identified using the PEM reference collection and published guides (Smale et al., 1995; Tuset et al., 2008). The number of each fish species in the stomach was estimated by counting the maximum number of either left or right otoliths. All otoliths were measured to the nearest $0.02 \mathrm{~mm}$ using a Zeiss binocular microscope fitted with an eyepiece graticule. Original prey dimensions and weights were back-calculated from otolith dimensions, using established regressions (Smale et al., 1995). Reconstituted weights of all fish and cephalopod remains from each stomach were summed to obtain a reconstituted meal weight for that stomach. In order to avoid inaccuracy associated with size reduction due to digestion, only undamaged otoliths and beaks were used in regressions to calculate the body size and weight of prey items. The majority of fish species were identified to species level.

In order to confirm identification of stomach contents that were not too fully digested, we extracted genomic DNA from three samples of soft tissue using the NucleoSpin DNA extraction kit (Machery-Nagel), following the manufacturer's protocol. We then used the universal primers VF2_t 1 and FishR2_ti (Ivanova et al., 2007) to amplify $\sim 700$ base pairs of the mtDNA cytochrome oxidase I (COI ) gene, using the thermal profile CO-2 as suggested in Ivanova et al. (2007). We included a negative control without DNA in the polymerase chain reaction (PCR) mix to ensure that contamination would not suggest false positives. PCR products were visually assessed on a $1 \%$ agarose gel stained with ethidium bromide and sequenced on an ABI 3730XL at Stellenbosch University. Sequences were compared to the GenBank data base using BLASTn. Determinations as to species were done without any prior knowledge about the results of the otolith identifications.

\section{RESULTS}

Total stomach contents weighed $758 \mathrm{~g}$, and consisted mainly of a mass of fish bones and associated flesh, otoliths, cephalopod beaks and eye lenses. No buccal masses or other soft parts (pens, etc.) from cephalopods were found.

In total, there were 159 eye lenses retrieved that could be referred to cephalopods and 127 to fish, representing a minimum number of 80 individual cephalopods and 64 individual fish. Interestingly these are substantially higher than the corresponding numbers of individuals calculated from beaks (36) and otoliths (36) respectively, implying that the eye lenses must be retained longer or digest more slowly than either beaks or otoliths. The relative proportions of cephalopod and fish are not significantly different using either eye lenses or beaks/otoliths (Chi-square with Yates correction $=$ $0.51, P=0.4751)$.

There were at least 13 species amongst the 36 cephalopods identified from beaks, with Histioteuthis atlantica (Hoyle, $1885)$ being easily the most abundant numerically $(\mathrm{N}=19)$. By mass, however, there were four species that made up $78.6 \%$ of the total, $H$. atlantica, Taningia danae Joubin, 1931, Ommastrephes bartrami (Lesueur, 1821) and Pholidoteuthis 'A' (Table 1).

There were at least eight species among the 36 fish identified from otoliths, with unidentified macrourids $(\mathrm{N}=14)$ and Beryx ?splendens $(\mathrm{N}=11)$ dominating numerically (Table 2). However, by mass B.?splendens was clearly the 
Table 1. Cephalopods identified from trace remains in the stomach of a $6.75 \mathrm{~m}$ female Tasmacetus shepherdi from Tristan da Cunha, with mass estimates derived from beak measurements.

\begin{tabular}{|c|c|c|c|c|c|c|}
\hline \multirow[t]{2}{*}{ Family } & \multirow[t]{2}{*}{ Closest identification } & \multicolumn{4}{|c|}{ Estimated mass (g) } & \multirow[t]{2}{*}{$\%$} \\
\hline & & $\mathbf{N}$ & Range & Average & Total & \\
\hline \multirow[t]{2}{*}{ Histioteuthidae } & Histioteuthis atlantica & 19 & $72-185$ & 141 & 2,679 & 30.4 \\
\hline & H. dofleini & 1 & 346 & 346 & 346 & $3 \cdot 9$ \\
\hline \multirow[t]{2}{*}{ Octopoteuthidae } & Taningia danae & 1 & 1770 & 1770 & 1770 & 20.1 \\
\hline & Octopoteuthis sp. & 2 & $120-230$ & 175 & 350 & 4 \\
\hline \multirow[t]{2}{*}{ Ommastrephidae } & Ommastrephes bartrami & 2 & $690-766$ & 728 & 1456 & 16.5 \\
\hline & Ommastrephid sp. & 1 & 341 & 341 & 341 & 3.9 \\
\hline \multirow[t]{2}{*}{ Pholidoteuthidae } & Pholidoteuthis 'A' & 1 & 1023 & 1023 & 1023 & 11.6 \\
\hline & Pholidoteuthis ? 'B' & 1 & 507 & 507 & 507 & 5.8 \\
\hline Lycoteuthidae & Lycoteuthis lorigera & 2 & 15 & 15 & 30 & 0.3 \\
\hline Cranchiidae & Taonius sp. & 1 & 107 & 107 & 107 & 1.2 \\
\hline Mastigoteuthidae & Mastigoteuthis sp. & 1 & 44 & 44 & 44 & 0.5 \\
\hline Enoploteuthidae & Pyroteuthis? & 1 & -150 & -150 & 150 & 1.7 \\
\hline \multirow[t]{2}{*}{ Brachioteuthidae } & Brachioteuthis picta & 1 & 3 & 3 & 3 & $<0.1$ \\
\hline & Brachioteuthis sp. & 1 & 3 & 3 & 3 & $<0.1$ \\
\hline Unidentified & & 1 & & & & \\
\hline Total & & 36 & & & 8809 & \\
\hline
\end{tabular}

most important item, forming $87.4 \%$ of the reconstituted fish mass. Otoliths of the largest Beryx specimen (positively identified as B. splendens Lowe, 1834) were recovered intact from inside remains of the skull, and at an estimated weight of $3.65 \mathrm{~kg}$ this was easily the largest food item ingested.

Sequences from the three samples of soft tissue analysed genetically were all identical and in GenBank were most similar to Beryx splendens with $92-93 \%$ identity, Beryx mollis Abe, 1959 with 90-91\% identity and Beryx decadactylus Cuvier, 1829 with $87 \%$ identity. It is therefore likely that these remains originated from a species of Beryx. The sequences in part presented with double peaks which probably represented contamination from other biological tissue present in the whale's stomach in lower volume. However, the sequence data seem to confirm the non-genetic analysis in which Beryx splendens was also the dominant food item.

Some of the smaller species eaten (such as Brachioteuthis and the myctophids) may have represented secondary prey items. Symbolophorus barnardi (Tåning, 1932) and Diaphus metopoclampus (Cocco, 1829), for instance, have been recorded in the diet of Beryx from the Canary Islands (Dürr \& González, 2002), while myctophids have been recorded as a prey item for Hoplostethus (Bulman \& Koslow, 1992).

The size composition of cephalopod prey items, expressed as dorsal mantle lengths as a proportion of the female's total length, is shown in Figure 2. The mode falls in the range 0.01-0.019 of female's length, and contains $61.8 \%$ of all cephalopods eaten, while the inter-quartile range of the distribution is 0.0078 and the largest item forms 0.052 of the female's length. According to the classification proposed by MacLeod et al. (2006), these characteristics would identify the species as a Group 3 odontocete, a group that includes the sperm whale, pygmy sperm whale and long-finned pilot whale and that is believed to represent highly specialized feeders concentrating on a narrow size-range of relatively small prey items, probably using suction. Otolith erosion and the scarcity of otolith/fish size regressions for some species prevent reconstruction of a size composition for fish prey, but a comparison of Tables 1 and 2 suggests that a wider size-range of fish than cephalopods was eaten, and

Table 2. Fish identified from trace remains in the stomach of a $6.75 \mathrm{~m}$ female Tasmacetus shepherdi from Tristan da Cunha, with mass estimates derived from the least eroded otolith measurements. Queries indicate where rough estimates made from other species in the same family, using Port Elizabeth Museum catalogue data.

\begin{tabular}{|c|c|c|c|c|c|}
\hline \multirow[t]{2}{*}{ Family } & \multirow[t]{2}{*}{ Closest identification } & \multicolumn{3}{|c|}{ Estimated mass (g) } & \multirow[t]{2}{*}{$\%$} \\
\hline & & $\mathbf{N}$ & Best estimate & Total & \\
\hline Trachichthyidae & Hoplostethus atlanticus & 1 & 729 & 729 & 4.2 \\
\hline \multirow[t]{2}{*}{ Berycidae } & Beryx ? splendens & 10 & 1169 & 11690 & 66.6 \\
\hline & Beryx splendens & 1 & 3651 & 3651 & 20.8 \\
\hline Opisthoproctidae & Opisthoproctus grimaldii & 1 & $? 15$ & 15 & 0.1 \\
\hline Gadiformes & Macrouridae & 14 & $? 20$ & 280 & 1.6 \\
\hline Lophiidae & Lophius sp. & 3 & $375^{*}$ & 1,125 & 6.4 \\
\hline Ophidiidae & Neobythites sp. & 1 & $? 11$ & 11 & 0.1 \\
\hline \multirow[t]{2}{*}{ Myctophidae } & Symbolophorus ?barnardi & 1 & $? 13$ & 13 & 0.1 \\
\hline & Diaphus ?metopoclampus & 2 & $? 10$ & 20 & 0.15 \\
\hline Unidentified & & 2 & $? 10$ & 20 & 0.15 \\
\hline Total & & 36 & & 17,554 & \\
\hline
\end{tabular}

*, Calculated using regression for Lophius vomerinus. 


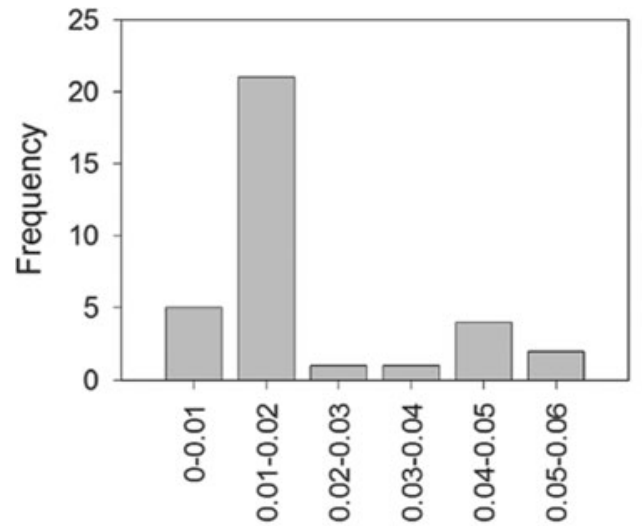

Cephalopod ML as proportion of whale's TL

Fig. 2. Size composition of cephalopods eaten by adult female Tasmacetus shepherdi stranded on Tristan da Cunha (ML, dorsal mantle length; TL, total length). Cephalopod size-data estimated from beak dimensions.

that the fish were generally larger $\left(11 / 36\right.$ being $>_{1} \mathrm{~kg}$, cf $2 / 36$ for cephalopods). It may therefore be premature to conclude much about the mode of prey capture used by Tasmacetus.

\section{DISCUSSIDN}

The researcher describing a predator's feeding habits from trace remains in its stomach is faced with a number of challenges. These can range from larger prey items being dismembered prior to ingestion (potentially lowering their identifiability if the head/buccal mass is not swallowed) to differing digestion rates for different prey types (Sekiguchi \& Best, 1997) and different erosion/retention times of trace elements in the stomach (Bowen, 2000). If the animal is found dead, then factors leading to its death (or the length of post-mortem time before examination) may also have influenced its recent food intake (or the interpretation thereof). All these can introduce errors or biases into attempts to make a quantitative assessment of the predator's diet. Nevertheless, when the predator is a rarely observed whale that apparently feeds at depth the investigator is left with little choice but to take the possibility of these factors into account when interpreting its stomach contents.

The presence of skeletal remains and associated soft parts identified genetically as Beryx splendens in the stomach of the stranded Tasmacetus, and the lack of any soft parts referable to cephalopods, confirmed that the whale's most recent meal had been dominated by fish. Nevertheless, the presence of their eye lenses and beaks indicated that the whale had been feeding previously on cephalopods. The relative importance of the two could be assessed numerically from eye lenses ( 1.25 cephalopod: 1 fish) or beaks/otoliths ( 1 cephalopod: 1 fish) and by mass from reconstituted data ( 0.5 cephalopod: 1 fish). However each of these indicators has its own inherent biases or uncertainties, and the most parsimonious conclusion would be that the whale had fed actively on both cephalopods and fish, apparently in separate feeding bouts, and to roughly equal extents. This raises interesting questions about the possible feeding strategy of the whale, and whether different prey types are sought on a spatial or temporal basis.
Such a strategy could be based in turn on the distribution and movements of its prey. Beryx splendens is a benthopelagic species that inhabits the outer shelf $(180 \mathrm{~m})$ and slope to at least $1300 \mathrm{~m}$ depth but usually between 400 and $600 \mathrm{~m}$, moving further from the bottom at night, often found over seamounts and underwater ridges (Paxton, 1999). Of the most important cephalopods in the stomach, little is known about the vertical distribution of Histioteuthis atlantica, but Young (1978) described H. dofleini (Pfeffer, 1912), also a prey species, as occurring in the day at $375-850 \mathrm{~m}(80 \%$ at $500-700 \mathrm{~m})$ rising at night to depths of $100-500 \mathrm{~m}(85 \%$ $150-300 \mathrm{~m})$. In the western North Pacific, adults of the large squid Taningia danae move from a depth of 600$900 \mathrm{~m}$ during the day to $240-500 \mathrm{~m}$ at night (Kubodera et al., 2007). Ommastrephes bartrami of a mantle length of $15-45 \mathrm{~cm}$ in the South Atlantic were found at a depth of $530-950 \mathrm{~m}$ (mostly $750-850 \mathrm{~m}$ ) in the day but at the surface at night (Moiseev, 1991). None of the cephalopods eaten is particularly associated with sea mounts (Clarke, 2007). The whale could therefore vary its foraging behaviour by shifting its distribution on and off continental slope and sea mount areas into oceanic areas to take advantage of the vertical distribution and shoaling behaviour of its prey.

Although based on a single stomach, this paper has added significantly to our knowledge about the feeding behaviour of a poorly known species, and to some extent has reconciled the apparently conflicting evidence from previous strandings. It is also unusual in using genetics independently from otoliths to identify a principal prey item. However further and more accurate information, especially on prey size and type, is required before the functional significance of the unusual dentition of Tasmacetus can be established.

None of the fish prey species seems to have been definitely recorded from the Tristan archipelago, although there are records of the congeneric Beryx decadactylus and a possible record of Symbolophorus barnardi (Andrew et al., 1995), but this may be a reflection of rather limited sampling, especially of benthic species.

\section{ACKNDWLEDGEMENTS}

The authors express their appreciation to Norman Glass and Warren Glass who helped retain and dissect the stranded whales on Tristan da Cunha and to Meredith Thornton and Gwen Penry who assisted with processing of the stomach contents in Cape Town. The cooperation of Ovenstone Agencies (Pty) Ltd in transporting the frozen material is much appreciated, as are the helpful comments of two referees. Natalie Goodall kindly allowed us to cite her unpublished observations. P.B.B. and M.J.S. acknowledge support from the National Research Foundation, South Africa, and S.v.d.H. thanks the Stellenbosch University Discretionary Fund for financial assistance.

\section{REFERENCES}

Andrew T.G., Hecht T., Heemstra P.C. and Lutjeharms J.R.E. (1995) Fishes of the Tristan da Cunha group and Gough Island, South Atlantic Ocean. Ichthyological Bulletin of the J.L.B. Smith Institute of Ichthyology 63, 1-43. 
Bowen W.D. (2000) Reconstruction of pinniped diets: accounting for complete digestion of otoliths and cephalopod beaks. Canadian Journal of Fisheries and Aquatic Sciences 57, 898-905.

Bulman C.M. and Koslow J.A. (1992) Diet and food consumption of a deep-sea fish, orange roughy Hoplostethus atlanticus (Pisces: Trachichthyidae), off south-eastern Australia. Marine Ecology Progress Series 82, 115-129.

Clarke M.R. (1986) A handbook for the identification of cephalopod beaks. Oxford: Clarendon Press.

Clarke M. (2007) Seamounts and cephalopods. In Pitcher T.J., Morato T., Hart P.J.B., Clarke M.R., Haggan N. and Santos R.S. (eds) Seamounts: ecology, conservation and management. Fish and Aquatic Resources Series. Oxford: Blackwell, pp. 207-229.

Dürr J. and González J.A. (2002) Feeding habits of Beryx splendens and Beryx decadactylus (Berycidae) off the Canary Islands. Fisheries Research 54, 363-374.

Goodall R.N.P., Dellabianca N., Boy C.C., Benegas L.G., Pimper L.E. and Ricciadelli L. (2008) Review of small cetaceans stranded or incidentally captured on the coasts of Tierra del Fuego, Argentina, over 33 years. Paper SC/6o/SM21 submitted to the Scientific Committee of the International Whaling Commission, Santiago, Chile, June 2008

Ivanova N.V., Zemlak T.S., Hanner R.H. and Hebert P.D.N. (2007) Universal primer cocktails for fish DNA barcoding. Molecular Ecology Notes 7, 544-548.

Kubodera T., Koyama Y. and Mori K. (2007) Observations of wild hunting behaviour and bioluminescence of a large, deep-sea, eightarmed squid, Taningia danae. Proceedings of the Royal Society, B 274, 1029-1034.

MacLeod C.D., Santos M.B., Lopez A. and Pierce G.J. (2006) Relative prey size consumption in toothed whales: implications for prey selection and level of specialisation. Marine Ecology Progress Series 326, 295-307.

Mead J.G. (1989) Shepherd's beaked whale-Tasmacetus shepherdi Oliver, 1937. In Ridgway S.H. and Harrison R. (eds) Handbook of marine mammals. Volume 4. River dolphins and the larger toothed whales. London: Academic Press, pp. 309-320.

Mead J.G. (2009) Shepherd's beaked whale Tasmacetus shepherdi. In Perrin W.F., Würsig B. and Thewissen J.G.M. (eds) Encyclopedia of marine mammals. 2nd edition. Amsterdam, Boston, Heidelberg,
London, New York, Oxford, Paris, San Diego, San Francisco, Singapore, Sydney and Tokyo: Academic Press, pp. 1011-1014.

Mead J.G. and Payne R.S. (1975) A specimen of the Tasman beaked whale, Tasmacetus shepherdi, from Argentina. Journal of Mammalogy 56, 213-218.

Moiseev S.I. (1991) Observation of the vertical distribution and behavior of nektonic squids using manned submersibles. Bulletin of Marine Science 49, 446-456.

Paxton J.R. (1999) Berycidae. Alfonsinos. In Carpenter K.E. and Niem V.H. (eds) FAO species identification guide for fishery purposes. The living marine resources of the western central Pacific. Volume 4. Bony fishes. Part 2 (Mugilidae to Carangidae). Rome: FAO, pp. 2218-2220.

Pitman R.L., Van Helden A., Best P.B. and Pym A. (2006) Shepherd's beaked whale (Tasmacetus shepherdi): information on appearance and biology based on strandings and at-sea observations. Marine Mammal Science 22, 744-755.

Sekiguchi K. and Best P.B. (1997) In vitro digestibility of some prey species of dolphins. Fishery Bulletin, US. 95, 386-393.

Smale M.J., Watson G. and Hecht T. (1995) Otolith atlas of southern African marine fishes. Ichthyological Monographs 1. Grahamstown, South Africa: J.L.B. Smith Institute of Ichthyology, 253 pp.

Tuset V.M., Lombarte A. and Assis C.A. (2008) Otolith atlas for the western Mediterranean, north and central eastern Atlantic. Barcelona: Scientia Marina, 72S1, $203 \mathrm{pp}$.

Young R.E. (1978) Vertical distribution and photosensitive vesicles of pelagic cephalopods from Hawaiian waters. Fishery Bulletin, US 76, $583-615$.

and

Xavier J.C. and Cherel Y. (2009) Cephalopod beak guide for the Southern Ocean. Cambridge: British Antarctic Survey, 129 pp.

\section{Correspondence should be addressed to:}

P.B. Best

Mammal Research Institute, University of Pretoria c/o Iziko South African Museum, PO Box 61, Cape Town, 80oo, South Africa email: pbest@iziko.org.za 